\title{
CRITICAL ASSESSMENT OF THE EXISTING DEFINITIONS OF BIM DIMENSIONS ON THE EXAMPLE OF SWITZERLAND
}

\author{
Adrian August Wildenauer \\ Faculty of Informatics and Statistics \\ University of Economics, Prague, Czech Republic
}

\begin{abstract}
Although the practical application of Building Information Modelling (BIM) is already widely accepted, not only in Switzerland, it is often either considered as a method or as a technology. Regrettably, often this utilization depends on the context of a person respectively a company interpreting the abbreviation. Consequently, this is accompanied by a different approach to the underlying processes, roles and procedures. A comprehensive overview of the compulsory BIM activities and the associated definitions is therefore essential - without clear and commonly agreed definitions, no unambiguous exchange between the parties concerned is conceivable as well. However, many definitions used in the Building Information Modelling sector are currently industry-based and not on a standardized or normative basis. These are amongst others the so called "Dimensions of BIM", which are heavily used in construction projects. Unfortunately, only a few companies in the construction industry are privileged to have a complete overview of the necessary cross-firm activities needed in the BIM context and the consequences in using these project based specifications, as the industry is quite diverse in terms of digital competency maturity, availability of trained staff and the effective use of operational software. Projectrelated definitions therefore tend to be the common standard in the processing of BIM projects. The aim of this paper is to provide an overview of the different definitions of BIM dimensions by means of a literature search and to evaluate it from the perspective of an ordering party.
\end{abstract}

Keywords: Building Information Modelling, BIM, BIM Dimensions.

Cite this Article: Adrian August Wildenauer, Critical Assessment of the Existing Definitions of BIM Dimensions on the Example of Switzerland. International Journal of Civil Engineering and Technology, 11(4), 2020, pp. 134-151.

https://iaeme.com/Home/issue/IJCIET?Volume=11\&Issue=4

\section{INTRODUCTION AND BACKGROUND}

Although Switzerland is well acquainted for its advancement and dissemination of technological tools and technical development [1], this has not progressed with the same intensity and velocity in every sector. Some industries are well known for their technological 
progress and progressive digital project management approach such as the pharmaceutical industry [2], with some industry sectors lagging, such as the construction industry. In order to overcome this gap, the Swiss construction industry is faced with enormous changes. It is undergoing a substantial transition due to digital transformation, after lagging for decades in terms of productivity and the low use of data related methods. To put simply, it is nothing more than transferring the industry from a paper driven to a data driven business. Main challenges in this transition are amongst others, the

- low spread of digital working methods with a corresponding low number of collaborative working environments [3,4]

- currently limited availability of trained staff as well as a higher level of expertise and a greater openness to new technology for implementing digital techniques and technologies $[5,6]$

- affected employees are not or only partially involved in the development of new methods and processes $[7,8]$

- awkward situation of low interoperability of different file formats and used programmes and therefore between different stakeholders $[9,10]$,

- increasing complexity on- and offsite for the planning and execution of projects [11],

- project and people based knowledge management systems instead of holistic approaches in construction related companies [12]

- mostly non-existing data governance for planning, construction and maintenance data [13],

- growing need for transparency and disclosure to stakeholders and public authorities, in particular as a contracting authority [14]

- lack of professionalism in ordering, handling and quality checking data, often described as missing order competence in the context of digital methods, such as BIM $[15,16]$

- a perfectible supply chain management [17] with a low use of data [18]

- non-continuous digital data flow for all phases from planning to maintenance causing up to $45 \%$ of the invested sum being mis-invested [19, 20, 21, 22]

- common understanding of the necessities and the corresponding abbreviations and terminology [23, 24]

The initially described problems do not occur by themselves but are interdependent. Taken this into account, one of the main challenges in Switzerland is to ensure a seamless digital data flow which would save substantial resources in the built environment process [25], leading to significant cost savings in all life cycle phases of a building [26]. These circumstances do not only refer to real estate, but also for infrastructure-based assets.

Kühne and Böhmann [27] argue that Information Technology (IT) is considered crucial and essential in this context, as companies turning from product-based offerings toward complex, service-oriented business models. This is particularly difficult in the construction industry, which proclaims to primarily manufactures highly individualised and unique products (e.g. a building). However, transforming is a long-term investment, as processes have to be changed accordingly [28]. Bradley, Li et. al. [29] describe it as a "central topic to the improvement of the [...] industry". Two factors are required and need to be aligned: The willingness of employers resp. employees to transform and a clear and concise political agenda. The topic has been placed on the political agenda and has received strong support. 
The Swiss National Council has already answered a political initiative positive in 2017 and has progressively endorsed the use of BIM [30]. A political agenda is yet missing.

\section{DEFINITION OF BUILDING INFORMATION MODELLING}

To describe Building Information Modelling (BIM) shortly, it is now possible in the history of construction by using BIM to link, store and reuse information in terms of attributes and properties to a specific building component in a three-dimensional computer-generated model enhancing cooperation, collaboration and coordination on- and offsite to improve productivity, effectiveness and efficiency. This model, often labelled as a digital twin, covers mostly all necessary data attributes for planning and construction, but can be used for operation and maintenance in case the data are correctly structured.

Principally, this model is a graphically visualized database [31]. BIM is one of the highest distinguished topics in the Swiss construction industry. Regrettably, there is not a standard definition of BIM [32]. Inopportunely, it is often considered as a complete project management (method) or as a technology. Therefore, this utilization depends often on the context a person respectively a company interpreting the abbreviation. This could be considered as a classic sender and recipient problem but has profound consequences. As a result, this is accompanied by a different approach to the underlying processes, roles and procedures [33], which results in an extensive interdependency between processes, procedures and methodology.

As aforementioned, "BIM as a term is used to present both a building information model and a collaborative methodology used by different project stakeholders." [34] A similar analogy was shown by Smith [35] who sees the "fundamental change to move from the traditional approach of project participants working on separate information pools typically with different and incompatible software technologies to a totally integrated common platform whereby participants can share and work on the same information."

Inevitably, Building Information Modelling or short BIM, is one of the most discussed topics on the construction and real estate market. Eynon [36] put it as one of the most unfortunate acronyms of today's time. As Eastman, Teicholz et. al. [37] already described it in 2011, "the term BIM is a popular buzzword used by software developers to describe the capabilities that their products offer". Captivatingly, nothing seems to have changed in the last decade. For some time now, the impression has been created that everything related to digitization in the construction industry seems to have BIM as a prefix or suffix. The first comprehensive study with advantages and disadvantages of BIM was done in 2019 [38] ages in terms of development.

\section{CHALLENGES FOR DATA AND PROJECT MANAGEMENT}

Already Harris 2010 [39] adverts to the fact that by the correct use of BIM supported technologies, it provides the project team the ability to communicate information essential for making business decisions. In a project comparison it was shown that BIM was not only to be useful for geometric modelling of a building's performance but also that in assisting in the management of construction projects [40]. Intriguingly, no country mandated BIM as a project management standard for their projects, mostly, they ordered digital models and proposed to leave the handling of the project in the hands of the planners and entrepreneurs. It is (still) considered as a revolutionary change in processes while planning, constructing and maintaining a building [41], although the theoretical foundations were laid almost 60 years ago [42]. Sattler et. al. [43] point to the unclarified interoperability that are the basis for these new processes. However, these are a basic requirement for successful data management, 
especially in such a defragmented industry as the construction industry. Gallaher et. al. [9] pointed already out in 2004 that "unfortunately, the construction industry has not yet used information technologies as effectively to integrate its design, construction, and operational processes." Alreshidi et. al. [13] showed in their research that one of the highest adoption barriers of BIM are business-related issues and problems in compatibility and reliability of data.

The use of BIM heavily relies on data and their effective use over the whole life cycle, allowing a single source of truth for specific data sets for all participants, ensuring collaboration, coordination and communication. This sets sophisticated challenges for participants to effectively and efficiently using digital planning methods such as BIM. Moreover, the use of data management tools is not widespread in the construction sector, impressively shown by e.g. Bilal et. al. [44] who see the construction industry for the arising amounts of data not well prepared. Interestingly, they see construction industry as "wellknown for fragmented data management practices" and consider it as an excellent starting point for Big Data. Yet, they point out that it is not the amount of data available that is important, but the quality. However, there is currently no established practice on how these [foreign] standards should be applied [in Switzerland] [45].

Considering the life cycle of an asset or an public infrastructure building, the integration of BIM with Asset Management is still a major challenge across the building lifecycle phases [46]. She is promoting the need for a holistic product-based life cycle management approach in the construction industry in order to foster innovation [47]. This is backed up by Alonso et. al. 2013 [48] stating that during the last years, "companies have invested a lot of money to solve this problem [of aligning IT and business], but have failed because they have focused on IT supply without taking into account business requirements." There is no widespread dissemination of digitised methods such as BIM in the planning and construction phase in Switzerland [49] and therefore, no alignment between IT and business.

Regretfully, only a few construction companies in the construction industry are privileged to have a complete overview of the necessary cross-lifecycle phase and cross-personal activities, IT necessities and business strategy needed in the BIM context, as the industry is quite diverse in terms of digital competency maturity, availability of trained staff and the effective use of operational software [50], which is not only the case in Switzerland [51]. It is often not surprising that many construction-related companies do not have either the personnel, financial or technological resources to keep up with technological developments. This results in a small number of competitive companies that SBB can contract as a public client and consequently leads to higher, basically preventable costs and other risks [52]. A comprehensive overview of the compulsory BIM activities and the associated definitions is therefore essential - without clear definitions, no unambiguous exchange between the parties concerned is conceivable as well $[43,15]$. Although, there is no comprehensive scientific study on the "readiness of BIM" in Switzerland, neighbouring countries face similar problems such as the low spread of ICT, the lack of functional ecosystems and non-existing IT Governance [53]. The trade association of Switzerland, economiesuisse, therefore called on politicians and the public in 2019 to adopt a holistic approach with all parties involved [54] to enable all participants to use BIM. Still, "there is a significant gap between the development of techniques [such as BIM] and strategies for asset owners to streamline BIM with AM [Asset Management] systems and derive business value from such integration" [55].

Despite these perfect starting conditions with political support, "Data Science (or Data Analytics) is [...] crucial to linking all of the innovative technologies in this sector [construction] and availability of data during construction or operation of the infrastructure is crucial and will facilitate significant improvement and transformations in the way work is 
carried out." [56]. Moreover, "unfortunately, the construction industry has not yet used information technologies as effectively to integrate its design, construction, and operational processes." [9] Hence, it is not enough just to apply and integrate data management principles. It is necessary to apply and learn. There has been no systematic approach or procedure established to capture those lessons learned in BIM [57].

What adds more to this point, the productivity in the sector is, compared to other industries, remarkably low $[58,59,60]$. Although construction counts for approximately $13 \%$ of the worlds GDP, the marginal growth of only $1 \%$ per year over the last 20 years is immanent [22]. Similar figures in Europe: $9 \%$ of the GDP according to the statistical numbers of Desruelle et. al. 2019 [56]. Moreover, they showed that almost 94\% of the construction companies in the EU 28 have less than 10 employees. This is remarkably, as it could indicate that these companies have not enough financial resources to introduce digital backed methods very easily and on a short-term notice.

In their important work, Eadie et. al. [61] identified in 2013 the significance of the cost of implementing BIM in terms and resources and training, which in their opinion act as a "substantial barrier within the construction industry [in the UK]". Moreover, in their literature review they reveal the main reasons for not using BIM on projects - mostly lack of expertise, resistance, reluctance to share information and eventually, investment costs. This is backed by Čuš-Babič 2014 [62], who, in addition to the aforementioned, also see the shortage of skilled workers and low profit margins. "In the construction industry, the project culture has been established over the corporate one." [63]

Although the advantages that can be achieved by the correct application of BIM in own projects [64] are well known by the participants, these advantages are often negated or not recognised in daily work. However, especially construction companies need to upgrade their technology in order to remain competitive and to use the new technical methods and tools in a targeted and benefits-oriented way (compare e.g. [65], [66], [67]). Ma et. al. [68] describe BIM as a disruptive information and communication technology, enabling project teams to manage a project via a model-based cooperative approach. However, they point out that it still facing several challenges in the building industry. A survey conducted by Wildenauer 2018 [69] confirms this formulation of the challenges already mentioned with reference to the Swiss construction market. It is necessary to train the staff in very short time to be capable in the use of BIM. BIM does not solve communication issues in the industry [70]. This leads to new roles and responsibilities. It is not the technique that enables communication but the people, compare [71]. Firdaus Razali et. al. [72] suggest the government invests more to train the people, meaning on basic and post gradual level.

\section{DIMENSIONS OF BUILDING INFORMATION MODELLING}

Despite not every participant in the construction supply chain being prepared for the future challenges in terms of digital planning, construction and operating of buildings, a lot of definitions are conquering the market. One of these obviously not internationally verified definitions are the so called "BIM dimensions" or "Dimensions of BIM", shortened with a sequence of following numbers starting with 3 and ending with D for Dimensions. (often 3-D, $3 \mathrm{D}$ or $3 \mathrm{D}$, herein after $\mathrm{nD}, \mathrm{n}>2$ ). These dimensions shall not be confused with the physical dimensions.

Regrettably, market participants are defining the following dimensions differently, with only the common understanding that 4D containing all necessary data for scheduling activities and 5D all data for cost-related tasks (e.g. [73]; [74]). However, this only pertains to the 
abbreviations for the overarching terms, not to the more precise specification of the services and related data fields and their corresponding data to be provided.

\subsection{History of BIM Dimensions}

The first time the term 4D was in 1995 [75], where it was logically described 4D as threedimensional CAD models that can show changes over the fourth dimension of time, which was justified by an included case study and later proven in a project study [76]. Hitherto, they did not describe the necessary data a client would need to order such a 4D CAD model, as they compared timed building processes with the interpretation of drawings and their relationship. Manifestly, it requires time before concepts from the university research world arrive on the commercial market. The use of time-relevant data as an important step towards the long-term viability of the construction industry to perform cost-relevant simulations [77]. He called this application of time-relevant data 4D CAD (Computer Aided Design). Matta et. al. [78] defined 4D by "[...] models combine building elements with construction activities to display the progression of construction over time; $3 D$ objects are linked to specific activities, which can appear or disappear at specified times according to the schedule." These documents were made available by the U.S. General Services Administration (US-GSA).

Janssens [79] described 4D as cost estimating and 5D as construction scheduling / coordination. Pramod Reddy [80] discussed 4D in 2011 with the background of the clear increase in the information content of digitally planned buildings and facilities, in order to simulate them in different states, alternatives and options over time and, if necessary, to also store the corresponding expenses. However, he also indicates that it is necessary to store all relevant data for the client in the model [and connected databases] in order to enable further processing of the data basis, e.g. with lean methods or other manufacturer-related services. Tauscher [81] discusses the topic of 4D but does not elaborate on it or define it further in his thesis. Liebich et. al. [82] defined in their expertise, which bases on the US-GSA Documents (see above) " $4 D$ refers to the linking of the $3 D$ building model with the schedule, which then allows for the simulation of time sequences, i.e. construction progress. $5 D$ refers to the link to the calculation, furthermore " $n D$ " refers to any links of other views to the virtual building model." However, they do not provide more detailed definitions and guidelines.

In 2012, the Senate of Finland introduced their "Common National BIM Requirements for Building Information Modeling" (COBIM) followed by procurement procedures which are compulsory for the further construction activity in Finland [83]. In part 8 of the 12-volume series they defined 4D as "4D animations for schedule assessment" but did not mention 5D. What is particularly praiseworthy is that they have already set the first basic requirements for BIM models and databases in 2012 - somewhat rudimentary due to the technical conditions, yet visionary and ahead of the technological development at the time [84]. Finland (2012) and Norway (2013) were the first in the world to introduce common BIM standards, including a legal framework, at a national level [85]. Countries such as the United Kingdom, the Netherlands and Italy followed several years later; among the European countries that were relatively late in establishing such a framework are France, Germany and Spain. In Norway [86] 4D ("planned project scheduling and resource allocation") and already 5D ("basic and details cost analysis") were defined differently. What should be mentioned positively is that they already assign and define the allocations, competencies and responsibilities to the individual roles; furthermore, many coordination rules are defined as well as the requirements for verification by means of automated rule programs, unfortunately not the corresponding data and data fields. However, these are given as examples. In Singapore, the BIM guidelines were adopted in the same year, 2013. Although they only have a short 4D definition ("construction scheduling and sequencing (applicable for Design \& Build projects)"), they, 
like the Norwegian documents, focus strongly on workflows, delivery results, their documentation and the validation of the BIM data in relation to the respective delivery phase of the planned project

Surprisingly, the famous Pennsylvania State University, an early mover in the implementation of BIM, only briefly mentioned these dimensions in its standard work for facility management in 2013 in a short reference to 4D, without elaborating further on this topic. They briefly comment the reference to coordination models [87]. In the same year, Simeone et. al. [88] defined it differently, with 3D data enriched with information about construction time (BIM 4D), costs estimation (BIM 5D) and life-cycle management (BIM 6D). Smith, 2014 [35] defines 4D as time, 5D as cost and 6D as facility management, which is only a part of the complete life cycle of an asset or a building. Following his own work, Smith 2016 [89], conducted a case study concerning the use of 5D. Concluding, he states that "the full potential of BIM models is generally not being achieved. Objects in models commonly lack the substantive data that is required for project cost managers and other construction professionals to fully reap the benefits the model has the capacity to provide."

Kensek and Noble 2014 [90] just mention in their standard work "BIM in current and future practice" that " $4 D$ and 5D models are desired because they provide greater cost estimation and detail before the construction phase" without defining 4D or 5D more in detail. Boton et. al. [91] highlighted in 2015 the fact that 4D modelling had already emerged well before the now flaring up acceptance of BIM, but only became more widespread with the emergence and spread of BIM. They validated the use of the 4D method in conjunction with clear data requirements on a specific pilot project in Luxembourg. Since this was a pilot project, they stated that it took some time to correctly model the individual components in the planning phase and link them to time data. Subsequently, however, significant less time was needed for this task in the following construction phase, as existing models could be used. These observations and this approach are supported by their investigations on the construction site [92]. In addition to the possible scheduling, they also see the safety approach for construction work at possibly unsafe locations on the construction site, which can be investigated in advance by $4 \mathrm{D}$.

This discussion of 4D was taken up by Mills 2016 [93] who combines the necessities of data with a Common Data Environment (CDE). By adding planning-relevant data to the data stored in the CDE, a 4D model is created that animates and illustrates the progress of the project. "Linking in cost data in order to support cost planning and generate estimates is known as 5D BIM, whilst the inclusion of information to support facilities management and operation is called 6D BIM." Eynon 2016 [36] defined 4D as assigning time attributes to parts of the model, so "that a view can be generated that shows the construction sequence". He puts 5D a combination of automated quantity take-off and an automated use of libraries for costs benchmarks whereas $6 \mathrm{D}$ is the as-built model at construction completion, "loaded with the $O+M$ [operation and maintenance] information." These necessary data and information were again not defined. Interestingly, in the same year a proposal was made [60] for a consolidated and merged approach of the different dimensions 3D, 4D and 5D, without defining them in detail but suggesting to enhance it e.g. with augmented-reality devices to generate the - as they call it - "next generation 5D Building Information Modeling". Nötzli et. al. 2016 [94] did not mention in their "Guidelines for BIM" the dimensions 4D and above, but offers a precise overview of the necessary data basis for the necessary life cycle-based data, including data fields, exemplary data content and specified use-cases with necessary output documents as well as the respective lifecycle phase in which the data is required based on Swiss standards. This is one of the few documents in literature research in which this granularity of requirements on the part of a building owner is specified. A survey [95], in 
which BIM is defined as the use of technology in a construction project, showed that Europe uses app. in $93 \%$ of the cases cost estimation based on BIM than other continents $(75 \%)$, comparable to the 4D approach. The use of BIM based scheduling was not stated.

Bodden et. al. [96] defined 4D in 2017 as technical possibility to link components of a BIM model with a schedule, which is "mainly used by general contractors as a use case at present". The use of 5D is not addressed. Bergmeister et. al. 2018 [97] point out in their extensive work that the linking of individual processes with components in BIM models can lead to the so-called " great effort" problem. Often the effort is too gargantuan to link the individual components with the scheduling data, when comparing the benefits achieved with the effort required. According to their statements, an automated linking of schedule and component data is only partially possible; furthermore, an automated definition of the dependencies between sub-processes cannot be easily automated. Planning variants are often difficult to compare with each other because they are often still done manually. It is therefore a major goal when processes are digitized to automate them.

\subsection{Ongoing development of BIM Dimensions}

Considering the practical application, Bauen Digital Schweiz [98], a Done Practice Approach association in the Swiss building sector, published a distinct statement in 2019 about the ambiguity of these dimensions: "First there was $2 D C A D$, then $3 D C A D$ - now there are additional dimensions to indicate the link between the BIM model and time, cost and schedule related information (although the exact order is not yet clear and is used differently depending on the literature).” This is backed by Charef et. al. in 2018 [99]. They examined in their ground-breaking work the acceptance of these different dimensions and the interpretation of them. Only 8 out of 10 BIM experts interviewed $(n=51)$ defined 6D and 7D and their interpretation and content consistently. Nevertheless, this confusérance continues in literature and sub consequently in projects, naturally. They state that even the term 4D has consistently changed over the years.

Arnal 2018 [100] counted to 10 Dimensions, with 6D the sustainability and $\mathrm{CO}_{2}$ accounting, $7^{\text {th }}$ is concerning operation and maintenance, $8^{\text {th }}$ Health and Safety, $9^{\text {th }}$ about Lean Management and the $10^{\text {th }}$ digitization. On the contrary, Bessert 2019 [101] describe 6D as the "completed building, as it was built. Additionally, specific information to objects, such as product information, warranty data etc. are added" as well as the $07^{\text {th }}$ dimension as the lifecycle planning.

Bender 2018 [102] combines the dimensions as intermediate steps to the BIM Maturity levels specified by the British NBS. They define 6D as the optimisation of energy efficiency or transport routes, which can of course be explained to some extent by sustainability considerations, but only covers part of it. In their opinion, there is a "classification into separate BIM models, which are enriched with individual attributes and then made available to other applications (4D to 7D)". In addition, the authors assume that at Level 3, the BIM dimensions will be incorporated into other bodies, such as the Integrated Project Delivery IPD, the Information Delivery Manual IDM and the International Framework of Dictionaries (formerly known as buildingsmart Data Dictionary). Level 3 is seen as a fully integrated project space.

Interestingly, the authors of this graph, the so-called BIM Wedge ([103]; [104]) did not refer to such dimensions, but always referred to the British standards, rules and specifications documents in force at the time, including the well-known Publicly Available Specifications, PAS 1192, which was more or less transferred to the ISO 19650-1 series and subsequent ones. They were driven by the need for the introduction of BIM in the British Construction Industry in order to foster innovation and boost effectiveness (compare amongst others [105]; [106] 
and [107]) and their consistent continuation to BIM Level 3. Level 3 is according to their specifications the holistic lifecycle asset management of a plant or building.

Interestingly enough, Koutamanis 2020 [108] points out that BIM can have only four dimensions due to the fact that most of the following dimensions can be calculated from the existing data generated by BIM and the chronological data is a number of events in a project which can be calculated.

Uhlenbruch 2019 [109] did not define the term 4D in detail but described it only briefly as "construction process planning", although she proposes in her $\mathrm{PhD}$ a system for analysing information in the planning, construction and operation of real estate. However, she points to the fact, that "Constantly evolving information technology and methods such as Building Information Modelling (BIM) raise expectations for an improved flow of information between project phases and participants. Even with the use of technology and new methods, however, it must first be clarified which information is required for which purpose and in which phase of the real estate life cycle this information must be available." Oesterreich and Teuteberg 2019 [110] agree on that point, too and strongly emphasise that "the degree of complexity grows with each BIM maturity level, since the increases in content, interoperability and collaboration pose new technical and social challenges to the adoption process." In their work they use the term BIM maturity level according to Succar synonymously with the term BIM dimensions. Merely a small number of construction companies are able to cope with this growing complexity of digital basics such as a comprehensive data management including data structuring and use of a Common Data Environment.

According to Jansen 2019 [111], Europe's largest professional institution for engineers, the German VDI, did not put these dimensions on their agenda for the development of BIM over the last and next years. In their glossary for the German Ministry of Transport, Liebich et. al. 2019 [23] define 4D as "3D model extended by schedule or execution processes (time). Allows the creation of 4D construction process visualization (4D-BIM)". Unfortunately, they do not go into detail about what data basis is required to create a schedule from a BIM model from either an entrepreneur's nor a client's view. Furthermore, the terminology of the document series to which the glossary belongs has not yet been adapted to the new ISO standard 19 650. According to Lu et. al. 2019 [112] 4 D BIM involves "time-related information being associated with different components of an information model", which can change over the process respectively the life cycle. The definition of 5D is less applicable the authors confirm that "Cost information is normally added as the fifth dimension to form the 5D BIM" Furthermore, they confirm that there are no widely accepted definitions beyond $5 \mathrm{D}$.

Attention should paid to the the danger that, if different models are used for the further processing of this planning and execution-relevant data in these dimensions, "silo-isation" will occur and the full potential and the exchange of data between the parties involved can no longer be guaranteed [113]. Daniotti et. al. further point out that this problem is not solved; a clear dialogue between all parties involved is needed to solve this problem. Matthews 2019 [114] raises the same issue and points out that these dimensions $\mathrm{nD}$ fuel classical perpetuate "paper-based" thinking. This paper-based business approach is backed by Shafiq et. al. 2013 [115].

\subsection{Correlation between Standards and the use of BIM Dimensions}

It is not a problem of existing standards; these have been driven forward for years by the relevant standardisation institutes. Internationally, the drivers are ISO (International Standardisation Organisation) and CEN (European Committee for Standardisation). 
Nationally, at Swiss level SIA (Swiss Association of Engineers and Architects) and CRB (Central Office for Rationalisation in Building). Nevertheless, there seems to be more of a challenge in the cooperation and the significance of terminology and terms between industry and standardisation. One topic here is the implementation of requirements in the very strongly defragmented industry, especially along the supply chain, which is one of the biggest challenges in this context. This implementation requires open, independent and nondiscriminatory standards that are known to all participants along this supply chain [116]. Every stakeholder is working on its own standard and sets of data, which intents a lot of coordination, collaboration and communication. However, "each partner retains responsibility for their own data but project managers are able to use BIM as one agreed source of truth' for their decision-making "[117]. This agreed source needs to be actively managed, which can only be successful based on standards.

However, open standards are based on what has already been achieved with technology, processes and data; they are a "thumbnail sketch" of what has been technically possible to date, not what is possible in the future. Unfortunately, standards are usually the lowest common denominator in a field. The application of standards is still basically voluntary and not legally prescribed. However, they become binding as soon as e.g. a judge accepts them as a basis for assessment. Furthermore, standards must be adopted by an overwhelming majority of experts and developed by consensus. This is challenging for a currently developing topic area such as the use of data-based methods such as BIM. (compare SNV 2020 [118]).

\section{CONCLUSION AND RECOMMENDATION}

The literature research concerned only a small chronological outline of the extensive BIM literature that has been published to date. However, a distinct bias is evident. Fundamentally, the digitisation of the construction industry is very welcome and long overdue to close the existing productivity gap with other sectors of the economy. However, if a new technology or method is introduced, it requires clear rules, definitions and ideally, standardized processes. Strangely enough, most market participants seem to have problems in applying BIM to their and the clients' benefit, using the terminology properly and understanding the different interpretations of these dimensions. This also implies that there must be agreement on whether BIM should be used as a technology or as a method. Naturally, this is viewed differently by many participants and countries in the evolvement of the construction industry towards a customer orientated business. The dimension numbers after 5D are a plethora of diverging explanations. It may therefore be more than a rhetorical question how a client should master the task, the use and the quality control of the results of the use of such BIM terms if the contracted construction experts are not able to do so. Furthermore, an almost overwhelming number of technical possibilities, such as software products, start-ups, applications, training etc. are available and possible, but is not used to the right extent.

Still, the determined data cannot be separated via self-chosen BIM dimensions for a client at all. This implies that data necessary for the scheduling control of a digital as well as real construction project cannot be separated from the data for cost calculations. It is therefore worth seriously questioning the allegedly added value that these putative dimensions provide for building owners and clients ordering a building. Building owners who have no experience with BIM often rely on consultants to place orders for them in the digital and analogue world.

It is becoming apparent that building owners shall not rely on non-standardized terms in the future, especially in the evolving BIM industry. When ordering a building or plant, it will therefore become increasingly important in future that the client does not use ambiguous or meaningless terms, but that the client's digital requirements for the finished product, i.e. the plant or building, are clearly defined in terms of data requirements. These definitions and 
requirements should not rely on the mentioned ambiguous market definitions but should ensure that the client's requirements are clearly outlined. As a result, clients must learn to increase their digital ordering competence, use it in a targeted manner and in future not to order general theoretical constructs, but to develop and formulate data requirements for their plants and buildings.

During the administrative introduction, the so-called BIM dimensions were often referred to in different contexts by different participants. Neither as a new customer in the BIM world nor as a BIM expert is it straightforward to understand how these dimensions converge, how they interact and how they can be combined when even the self-proclaimed experts disagree. Consequently, it can be concluded that it is not advisable to use these dimensions. There is neither a uniform standardised definition of the BIM Dimensions $\mathrm{nD}$, with $\mathrm{n} \geq 4$, nor a mutual agreement in the industry about 4D and 5D, but not about the necessary data.

Therefore, building owners respectively clients ordering a building project which is executed with BIM methods should not rely on ordering "BIM dimensions" such as 4D (or $\mathrm{nD}$, with $\mathrm{n} \geq 4$ ) solely. To overcome this gap, clients shall clearly state which data and information they need at which point in the project and order it accordingly. Moreover, standardisation and normative bodies are called to action to harmonise these "BIM Dimensions".

\section{REFERENCES}

[1] Dutta; Lanvon; Wunsch-Vincent: Energizing the world with innovation $-11^{\text {th }}$ Edition. World Intellectual Property Organisation, The Global innovation index11th edition (2018), World Intellectual Property Organisation, Geneva, 2018.

[2] Hwang: Development of Industry-Specific Metrics for Benchmarking Pharmaceutical Construction Project Performance. Singapore, National University of Singaoire, Conference Paper, 2008.

[3] Grilo; Jardim-Goncalves: Value proposition on interoperability of BIM and collaborative working environments. In: Automation in Construction 19 (2010), Issue 5, pp. 522-530.

[4] Gehring; Lux; Tietz et al.: Digitalisierung in Schweizer Klein- und Mittelunternehmen KMU-Spiegel 2017 (2017), pp. 1-60.

[5] Egger; Hausknecht; Liebich et al.: BIM-Leitfaden für Deutschland - Information und Ratgeber - Endbericht (2013).

[6] Andujar-Montoya; Galiano-Garrigos; Rizo-Maestre et al.: BIM and Lean Construction interactions - A state of the art review. In: Wilde; Mahdjoubi; et. al. (Hrsg.): Building Information Modelling (BIM) in Design, Construction and Operations III, WIT Transactions on The Built Environment. WIT PressSouthampton UK, Seville, Spain, 2019, pp. 1-13.

[7] Peter: Arbeitswelt 4.0 - Arbeitswelt 4.0 Als KMU die Arbeitswelt der Zukunft erfolgreich gestalten. Fachhochschule Nordwestschweiz, Olten, 2019.

[8] Centeno; Vuorikarie; Punie et al.: Developing digital competence for employability Engaging and supporting stakeholders with the use of DigComp. European Digital Competence Framework,

2019, https://publications.jrc.ec.europa.eu/repository/bitstream/JRC118711/jrc118711_digcomp 4empl_stakeholders_consultation_ws_report_v1.0_in_pubsy_final_v0.pdf [Access at: 13.04.2020].

[9] Gallaher; O'Connor; Dettbarn et al.: Cost Analysis of inadequate Interoperability in the US Capital Facilities Ausgabe 2004. 
[10] da Silva Serapião Leal; Guédria; Panetto: An ontology for interoperability assessment: A systemic approach. In: Journal of Industrial Information Integration 16 (2019), pp. 1-13.

[11] Bani Feriel; Ilham; Boudemagh Souad: Investigating the Synergy of Integrated Project Delivery and Building Information Modeling in the Conservation of the Architectural Heritage. In: Journal of Contemporary Urban Affairs 2 (2018), Issue 3, pp. 67-77.

[12] Eken; Bilgin; Dikmen Birgonul: A Lessons Learned Database Structure for Construction Companies. In: Procedia Engineering 123 (2015), pp. 135-144.

[13] Alreshidi; Mourshed; Rezgui: Factors for effective BIM governance. In: Journal of Building Engineering 10 (2017), pp. 89-101.

[14] Fabig; Haasper: IT Management - Erfahrungen und Trends. Books on Demand, Norderstedt, 2016.

[15] Wildenauer. Verschenkter Datenschatz [online] - Lebenszyklusbasiertes Datenmanagement (Life Cycle Data Management). In: Build.-Ing. 2, 2018, 2, 46-49 [Access at: 19.01.2020], https://www.build-ing.de/fachartikel/detail/verschenkterdatenschatz/.

[16] Hanski: Supporting strategic asset management in complex and uncertain decision contexts. Lappeenranta, Lappeenranta-Lahti University of Technology LUT, Doctor of Science, 2019.

[17] Madenas, N.; Tiwari, A.; Turner, C.J. et al.: Information flow in supply chain management: A review across the product lifecycle. In: CIRP Journal of Manufacturing Science and Technology 7 (2014), Issue 4, pp. 335-346.

[18] Manyika; Chui et.al.: The internet of things: mapping the value behind the hype (2015).

[19] Barber: Understanding internally generated risks in projects. In: International Journal of Project Management 23 (2005), Issue 8, pp. 584-590.

[20] Flyvbjerg: Cost Overruns and Demand Shortfalls in Urban Rail and Other Infrastructure. In: Transportation Planning and Technology 30 (2007), Issue 1, pp. 9-30.

[21] Teicholz, P. (Hrsg.): BIM for facility managers. Wiley, Hoboken NJ, 2013.

[22] Barbosa; Woetzel; Mischke et al.: Reinventing Construction - A route to higher productivity. McKinsey, 2017, https://www.mckinsey.com/industries/capital-projects-andinfrastructure/our-insights/reinventing-construction-through-a-productivity-revolution [Access at: 25.01.2019].

[23] Liebich; Tulke: BIM4INFRA2020 - Handreichungen und Leitfäden - Glossar, 2019, https://bim4infra.de/wp-content/uploads/2019/07/BIM4INFRA2020_AP4_Glossar.pdf [Access at: 01.01.2020].

[24] Wildenauer: Evaluating 100+ use cases for BIM. buildingsmart Finland, InfraBIM Open 2020, Tampere, Finnland, 2020.

[25] Olsson; Johansson; et. al.: Unbroken digital data flow in the Built Environment - a case study in Sweden. In: ISPRS - International Archives of the Photogrammetry, Remote Sensing and Spatial Information Sciences XLII-2/W13 (2019), pp. 1347-1352.

[26] Thanthirige: Cost Saving Benefits Derived through the Utilisation of Building Information Modeling (BIM) in the Design and Construction Process - Year of publication unknown, upload in 2020. San Fernando, Trinidad and Tobago, School of Higher Education SHEL, not available, 2020.

[27] Kühne; Böhmann: Data-driven Business Models - building the bridge between data and value. In: ECIS (ed.): ECIS 2019 Proceedings - Proceedings of the 27 th European Conference on Information Systems (ECIS), 2019. 
[28] Ciribini; Mastrolembo Ventura; Paneroni: Implementation of an interoperable process to optimise design and construction phases of a residential building: A BIM Pilot Project. In: Automation in Construction 71 (2016), pp. 62-73.

[29] Bradley; Li; Lark et al.: BIM for Infrastructure: An Overall Review and Constructor Perspective. In: Automation in Construction 71 (2016), pp. 139-152.

[30] Dobler: Digitalisierung im Bauwesen. Wo steht die Schweiz? Interpellation des Eidgenössischen Parlamentes. Curia Vista der Bundesversammlung Bern, online, https://www.parlament.ch/de/ratsbetrieb/suche-curia-vista/geschaeft?AffairId=20173140 [Access at: 04.04.2020], 2017.

[31] Solihin, W.; Eastman, C.; Lee, Y.-C. et al.: A simplified relational database schema for transformation of BIM data into a query-efficient and spatially enabled database. In: Automation in Construction 84 (2017), pp. 367-383.

[32] Czmoch; Pękala: Traditional Design versus BIM Based Design. In: Procedia Engineering 91 (2014), pp. 210-215.

[33] Saraireh; Haron: Understanding the Conceptual of Building Information Modeling: A Literature Review. In: International Journal of Civil Engineering and Technology 11 (2020), Issue 1.

[34] Moreno; Olbina; et. al.: BIM Use by Architecture, Engineering, and Construction (AEC) Industry in Educational Facility Projects. In: Advances in Civil Engineering 2019 (2019), Issue 2, pp. 1-19.

[35] Smith: BIM Implementation - Global Strategies. In: Procedia Engineering 85 (2014), pp. 482-492.

[36] Eynon: Construction Manager’s BIM Handbook. Wiley, New York, 2016.

[37] Eastman; Teicholz; et. al.: BIM Handbook - A Guide to Building Information Modeling for Owners, Managers, Designers, Engineers and Contractors. John Wiley \& Sons, New York, NY, 2011.

[38] Seyis: Pros and Cons of Using Building Information Modeling in the AEC Industry. In: Journal of Construction Engineering \& Management, Vol. 145 (2019), Iss. 8.

[39] Harris: Integration of BIM and Business Strategy. Evanston, IL, Northwestern University, Master Thesis, 2010.

[40] Bryde; Broquetas; et. al.: The project benefits of Building Information Modelling (BIM). In: International Journal of Project Management 31 (2013), Issue 7, pp. 971-980.

[41] Gholizadeh; Esmaeili; et. al.: Diffusion of Building Information Modeling Functions in the Construction Industry. In: Journal of Management in Engineering 34 (2018), Issue 2, p. 4017060.

[42] Engelbart: Augmenting Human Intellect: A Conceptual Framework (1962), Issue 3578.

[43] Sattler; Lamouri; et. al.: Interoperability aims in Building Information Modeling exchanges: a literature review. In: IFAC-PapersOnLine 52 (2019), Issue 13, pp. 271-276.

[44] Bilal; Oyedele; et. al.: Big Data in the construction industry: A review of present status, opportunities, and future trends. In: Advanced Engineering Informatics 30 (2016), Issue 3, pp. 500-521.

[45] Schneider; Klaus: Digitalisierung der Bauindustrie durch BIM - Newsletter Oktober 2017, 2017, www.swlegal.ch [Access at: 31.12.2019]. 
[46] Jupp: Incomplete BIM Implementation: Exploring Challenges and the Role of Product Lifecycle Management Functions - IFIP International Federation for Information Processing 2013. In: 409 (2013), pp. 630-640.

[47] O'Connor: Real Innovation Requires More Than an R\&D Budget. In: Harvard Business Review (2019).

[48] Alonso; Verdún; et. al.: Case Study of Strategic IT Demand Management Organizations Exploratory Results. In: Procedia Technology 9 (2013), pp. 900-909.

[49] Kassem, M.; Succar: Macro BIM adoption: Comparative market analysis. In: Automation in Construction 81 (2017), pp. 286-299.

[50] Wildenauer: Initial development and BIM Setup of implemented projects in Switzerland. In: Rickers; Ammermann (Hrsg.): Lake Constance 5D-Conference 2016. Hochschule Konstanz, Constance, 2016, 98-112.

[51] Succar; Poirier: Lifecycle information transformation and exchange for delivering and managing digital and physical assets. In: Automation in Construction 112 (2020), p. 103090.

[52] Zou; Kiviniemi; et. al.: A review of risk management through BIM and BIM-related technologies. In: Safety Science 97 (2017), pp. 88-98.

[53] Bertschek; Niebel; et. al.: Zukunft Bau - Beitrag der Digitalisierung zur Produktivität in der Baubranche - Endbericht. Leibniz-Zentrum für Europäische Wirtschaftsforschung GmbH, 10.08.17.7-17.48, 1, Mannheim, 2019.

[54] Lanz; Ruff; Federer: Infrastrukturbericht 2019 - Verlässlicher, dynamischer, innovativer - für zukunftsfähige Schweizer Infrastrukturen (2019).

[55] Munir, M.; Kiviniemi, A.; Jones, S.W.: Business value of integrated BIM-based asset management. In: Engineering, Construction and Architectural Management 26 (2019), Issue 6, pp. 1171-1191.

[56] Desruelle; et. al.: Digital Transformation in Transport, Construction, Energy, Government and Public Administration - JCR Science for Policy Report. Public Office of the European Union, Luxembourg, 2019.

[57] Liu; Jallow; et. al. (Hrsg.): Building Knowledge Modeling: Integrating knowledge in BIM. Pennsylvania State University, University of Auckland, New Zealand, 2013.

[58] Teicholz, P.: U.S. Construction Labor Productivity Trends, 1970-1998. In: Journal of Construction Engineering \& Management 127 (2001), Issue 5, p. 427.

[59] Getuli; Ventura; Capone et al.: A BIM-based Construction Supply Chain Framework for Monitoring Progress and Coordination of Site Activities. In: Procedia Engineering 164 (2016), pp. 542-549.

[60] Agarwal; Chandrasekaran; Sridhar: Imagining construction's digital future, 2016, https://www.mckinsey.com/ /media/McKinsey/Industries/Capital\%20Projects\%20and\%2 OInfrastructure/Our\%20Insights/Imagining\%20constructions\%20digital\%20future/Imagini ng-constructions-digital-future.ashx [Access at: 07.12.2019].

[61] Eadie; Browne; Odeyinka et al.: BIM implementation throughout the UK construction project lifecycle: An analysis. In: Automation in Construction 36 (2013), pp. 145-151.

[62] Čuš-Babič; Rebolj; Nekrep-Perc, P.: Supply-chain transparency within industrialized construction projects. In: Computers in Industry 65 (2014), Issue 2, pp. 345-353.

[63] Serpell; Díaz: Linking Central Business Processes of Construction Companies with the Performance of Construction Operations: A Preliminary Exploration. In: Procedia Engineering 164 (2016), pp. 376-382. 
[64] Ilozor; Kelly: Building Information Modeling and Integrated Project Delivery in the Commercial Construction Industry: A Conceptual Study. In: Journal of Engineering, Project and Production Management (2011), pp. 23-36.

[65] Matarneh; Danso-Amoako; Al-Bizri et al.: Building information modeling for facilities management: A literature review and future research directions. In: Journal of Building Engineering 24 (2019), p. 100755.

[66] Arayici: Building Information Modeling. Bookboon, online, 2015.

[67] Lindblad; Vass: BIM Implementation and Organisational Change: A Case Study of a Large Swedish Public Client. In: Procedia Economics and Finance 21 (2015), pp. 178184.

[68] Ma; Xiong; Olawumi et al.: Conceptual Framework and Roadmap Approach for Integrating BIM into Lifecycle Project Management. In: Journal of Management in Engineering 34 (2018), Issue 6, p. 5018011.

[69] Wildenauer: Auswertung Online-Umfrage 2018 - BIM in der Schweizer Immobilienwirtschaft - eine Situationsanalyse. In: 2 (2018).

[70] Koseoglu; Arayici: Airport building information modelling. Routledge, Abingdon, Oxon, 2020.

[71] Goh; Toh; Ang: Enhancing Communication in Construction Industry through BIM. In: Yang, L.; Kantola, J.; Hoyas, A. de et al. (eds.): Proceedings of the $11^{\text {th }}$ International Conference On Innovation And Management, Vols I And II. Vaasa Univ Appl Sci NEF Pontif Cathol Univ Sao Paulo Yamaguchi Univ Eindhoven Univ Technol Tilburg Univ Wuhan Univ Technol. Wuhan Univ Technology PRESS, 2014, pp. 313-324.

[72] Firdaus Razali; Azam Haron; Hassim et al.: A Review: Application of Building Information Modelling (BIM) over Building Life Cycles. IOP Conference Series: Earth and Environmental Science, 2019, https://iopscience.iop.org/article/10.1088/17551315/357/1/012028/pdf.

[73] Castellano-Román; Pinto-Puerto: Dimensions and Levels of Knowledge in Heritage Building Information Modelling, HBIM: The model of the Charterhouse of Jerez (Cádiz, Spain). In: Digital Applications in Archaeology and Cultural Heritage 14 (2019), e00110.

[74] Tizani (Hrsg.): Experiences using building information modeling for a construction project. National Taiwan University, Taipei, Taiwan, 2010.

[75] Collier; Fischer: Four-Dimensional Modeling in Design and Construction CIFE Technical Report \#101. Center for integrated Facility Engineering, 1995, https://stacks.stanford.edu/file/druid:zd669fn2067/TR101.pdf [Access at: 31.12.2019].

[76] Fischer; Kam: PM4D Final Report - CIFE Technical Report Number 143, 2002, https://stacks.stanford.edu/file/druid:gq910sm0070/PM4D_Final_Report.pdf [Access at: 31.12.2019].

[77] Hannon: Emerging Technologies for Construction Delivery - A Synthesis of Highway Practice. niversity of Southern Mississippi. National Academies of Sciences, Engineering, and Medicine, Washington, D.C., 2007.

[78] Matta; Kam; Ho et al.: GSA Building Information Modeling Guide Series 04 - 4D Phasing. Public Buildings Service, Office of the Design\&Construction, 2009, https://www.gsa.gov/real-estate/design-construction/3d4d-building-informationmodeling/bim-guides/bim-guide-04-4d-phasing [Access at: 31.12.2019].

[79] Janssens: BIM Implementation - An owner's guide to getting started (2010). 
[80] Pramod Reddy: BIM for building owners and developers - Making a business case for using BIM on projects. Wiley, 2011.

[81] Tauscher: Vom Bauwerksinformationsmodell zur Terminplanung - Ein Modell zur Generierung von Bauablaufplänen. Weimar, Professur Informatik im Bauwesen, Dissertation, 2011.

[82] Liebich; Schweer; Wernik: Die Auswirkungen von Building Information Modeling (BIM) auf die Leistungsbilder und Vergütungsstruktur für Architekten und Ingenieure sowie auf die Vertragsgestaltung - Schlussbericht. im Auftrag des Bundesinstituts für Bau-, Stadtund Raumforschung (BBSR) im Bundesamt für Bauwesen und Raumentwicklung, 2011, https://www.irbnet.de/daten/baufo/20118035383/Endbericht.pdf [Access at: 04.01.2020].

[83] RTS: Common BIM Requirements 2012 Series 8 - Use of models for visualization, 2012, https://www.buildingsmart.de/kos/WNetz?art=File.download\&id=1049\&name=cobim_08 _visualization_v1.pdf.

[84] RTS: Common BIM Requirements 2012 Series 1 - General Part - Version 1.0, 2012, https://www.buildingsmart.de/kos/WNetz?art=File.download\&id=1048\&name=cobim_01 _general_requirements_v1.pdf [Access at: 04.01.2020].

[85] Kumar (ed.): Contemporary strategies and approaches in 3-D information modeling. IGI Global, Hershey, PA, 2018.

[86] Statsbygg: BIM Manual 1.2.1 (2013), pp. 1-98.

[87] Messner; Anumba; Leicht et al.: BIM Planning Guide for Facility Owners - Version 2.0. Pennsylvania State University, 2013.

[88] Simeone; Schaumann; Kalay et al.: Adding users' dimension to BIM. In: EAEA-11 conference 2013 (2013).

[89] Smith: Project Cost Management with 5D BIM. In: Procedia - Social and Behavioral Sciences 226 (2016), pp. 193-200.

[90] Kensek; Noble: Building Information Modeling - BIM in Current and Future Practice. Wiley, Hoboken, 2014.

[91] Boton; Kubicki; et. al.: The Challenge of Level of Development in 4D/BIM Simulation Across AEC Project Lifecyle. A Case Study. In: Procedia Engineering 123 (2015), pp. 5967.

[92] Trani; Cassano; et. al.: BIM Level of Detail for Construction Site Design. In: Procedia Engineering 123 (2015), pp. 581-589.

[93] Mills: What is 4D BIM?, 2016, https://www.theb1m.com/video/what-is-4d-bim [Access at: 27.12.2019].

[94] Nötzli; Stoy; Uhlenbruch: Building Information Modeling - BIM Leitfaden Eidgenössische Technische Hochschule Zürich (2016).

[95] Jung; Lee: The Status of BIM Adoption on Six Continents. In: International Journal of Civil and Environmental Engineering 9 (2015), Issue 5, pp. 512-516.

[96] Bodden; Elixmann; Eschenbruch: BIM-Leistungsbilder (2017), Issue 2, pp. 1-64.

[97] Bergmeister; Fingerloos; et. al. (Hrsg.): Beton-Kalender 2018 - Bautenschutz, Brandschutz. Wilhelm Ernst \& Sohn, Beton-Kalender Heft 107.2018, Ernst \& Sohn a Wiley brand, Berlin, Germany, 2018.

[98] Bauen Digital Schweiz: Glossar 4D-5D-6D, 2018, https://bauendigital.ch/de/produkte/glossar/\#4d-5d-6d [Access at: 14.12.2019]. 
Critical Assessment of the Existing Definitions of BIM Dimensions on the Example of Switzerland

[99] Charef; Alaka; Emmitt: Beyond the third dimension of BIM: A systematic review of literature and assessment of professional views. In: Journal of Building Engineering 19 (2018), pp. 242-257.

[100] Arnal: Why don't we start at the beginning? - The Basics of a Project Lean Planning and Pre-Construction. BIMCommunity, 2018, https://www.bimcommunity.com/news/load/490/why-don-t-we-start-at-the-beginning [Access at: 25.12.2019].

[101] Bessert: BIM im FM - Building Information Modeling - der Standard zur Digitalisierung Ihrer Gebäudeverwaltung, 2019, https://www.etask.de/softwareprodukte/bim-im-fm/ [Access at: 25.12.2019].

[102] Bender; Härtig; Jaspers et al.: Building Information Modeling. In: May, M. (ed.): CAFMHandbuch. Springer Fachmedien Wiesbaden, Wiesbaden, 2018, pp. 295-324.

[103] Bew; Richards: BIM Maturity Model - (no official source found; original source: presentation, not available online). buildingsmart Construct IT Autumn 2008 Members' Meeting, 2008, https://www.cdbb.cam.ac.uk/system/files/documents/BISBIMstrategyReport.pdf.

[104] Bew; Lorimer; Wolstenholme et al.: A report for the Government Construction Client Group - Building Information Modelling Working Party Strategy Paper (2011).

[105] Latham: Constructing the Team - Final report of the Government/Industry Review of Procurement and contractual arrangements in the UK construction industry. In: HMSO (1994), ISBN 011752994 X.

[106] Egan: Rethinking Construction - Report of the Construction Task Force (1998).

[107] Wolstenholme: Never waste a good crisis - A review of progress since Rethinking Construction and Thoughs of our future (2009).

[108] Koutamanis: Dimensionality in BIM: Why BIM cannot have more than four dimensions? In: Automation in Construction 114 (2020), p. 103153.

[109] Uhlenbruch: Smart Data - Systematik zur Analyse von Informationen in Planung, Bau und Betrieb von Immobilien, Schriftenreihe Bauökonomie Heft 6, De Gruyter Oldenbourg, München, 2019.

[110] Oesterreich; Teuteberg: Behind the scenes: Understanding the socio-technical barriers to BIM adoption through the theoretical lens of information systems research. In: Technological Forecasting and Social Change 146 (2019), pp. 413-431.

[111] Jansen: Building Information Modeling - VDI-Richtlinien zur Zielerreichung, 2019, https://www.vdi.de/fileadmin/pages/vdi_de/redakteure/ueber_uns/fachgesellschaften/GBG /dateien/Bauen-und-Gebaeudetechnik-Bautechnik-Agenda-Building-InformationModeling.pdf [Access at: 31.12.2019].

[112] Lu; Tse; Lai: BIM and big data for construction cost management. Routledge, London, 2019.

[113] Daniotti; Pavan; Spagnolo et al.: BIM-based collaborative building process management, Springer tracts in civil engineering, Springer, Cham, Switzerland, 2020.

[114] Matthews: How Smart Contracts are Reducing Inefficiencies in Construction. CURT, 2019, https://www.curt.org/how-smart-contracts-are-reducing-inefficiencies-inconstruction/ [Access at: 31.12.2019].

[115] Shafiq; Matthews; Lockley: A study of BIM collaboration requirements and available features in existing model collaboration systems. In: Journal of Information Technology in Construction 18 (2013), pp. 148-161. 
[116] Maier: Building Information Modeling - Grundzüge einer open BIM Methodik für die Schweiz, 2015, https://www.ebp.ch/sites/default/files/unterthema/uploads/ki-leitfadenopen-bim.pdf [Access at: 01.03.2020].

[117] Rudden; Castaing; Alsem et al.: BIM and ISO 19650 from a project management perspective - Organization and digitization of information about buildings and civil engineering works, including building information modelling (bim). efca, online, 2019.

[118] SNV: Was regeln Normen? SChweizerische Normenvereinigung SNV, 2020, https://www.snv.ch/de/ueber-normen/was-regeln-normen.html [Access at: 29.02.2020]. 